\title{
Partition coefficients of some acetate esters and alcohols in water, blood, olive oil, and rat tissues
}

\author{
T Kaneko, P-Y Wang, A Sato
}

\begin{abstract}
Partition coefficients of hydrophilic organic solvents $\left(C_{1}-C_{5}\right.$ acetate esters and alcohols) in distilled water, olive oil, human blood, and various rat tissues (blood, liver, kidney, brain, muscle, and fat) were determined. Water/air partition coefficients were measured by a new vial equilibration technique, which needs no direct measurement of the concentration in either the liquid phase or the gas phase, but only the gas chromatographic peak areas from both phases. Once the water/air partition coefficients had been measured, the blood/air, oil/air, and tissue/air partition coefficients could be measured by the previously developed vial equilibration method, which uses gas chromatographic peak areas from the gas phases in the sample (which contains test material) and the reference (which contains no test material) vessels. The alcohols tested were 32 (methanol) to 128 (n-pentanol) times more hydrophilic than the corresponding esters compared with oil/water partition coefficients. In general, water/air partition coefficients decreased and oil/air partition coefficients increased in proportion to the number of carbon atoms. Blood/air coefficients of alcohols were almost parallel to water/air partition coefficients, whereas no such relation was found with acetate esters. $n$-Isomers of both acetate esters and alcohols were found to be more soluble in water, blood, oil, and tissues than the corresponding iso-isomers.
\end{abstract}

(Occup Environ Med 1994;51:68-72)

Department of Environmental Health, Medical University of Yamanashi, Tamaho, Yamanashi, 409-38 Japan Tapan P-Y Wang A Sato

Requests for reprints to Dr Akio Sato, Department of Environmental Health, of Environmental Heal Medical University of Yamanashi, 409-38 Japan.

Accepted 22 February 1993 Physiologically based pharmacokinetic (PBPK) modelling provides us with a useful tool for insight into the pharmacokinetic profiles of organic solvents. ${ }^{12}$ Many reports have described PB-PK models for lipophilic solvents, ${ }^{1-7}$ whereas few discuss such models for hydrophilic compounds. ${ }^{8-10}$ Partition coefficients between blood and air and between tissue and blood are the prerequisite values for developing a PB-PK model. Lack of partition data may be one reason why a model of this kind has not been established for hydrophilic solvents.

We reported a simple vial equilibration method to determine partition coefficients between liquid (including tissue homogenates) and air. ${ }^{11}$ Partition coefficients of many volatile compounds in various fluids and tissues have been measured successfully with this technique, ${ }^{11-15}$ which needs no direct measurement of the concentration either in the liquid or in the air phase. It needs only the gas chromatographic peak heights or peak areas of the air in the sample (which contains test material) and reference (which contains no test material) vessels. The partition coefficients of lipophilic compounds were measured easily by this method, but applying it to hydrophilic compounds was difficult because of their high water solubility.

Fiserova-Bergerova and Diaz reported blood/air and tissue/air partition coefficients of several hydrophilic compounds (alcohols and ketones) ${ }^{16}$ that were determined by a method essentially the same as the one we reported previously ${ }^{11}$ except that their method uses a gas standard in place of an aqueous standard. Blood/air partition coefficients of some hydrophilic solvents were also measured by other investigators ${ }^{17}$ by methods based on the same principle as that used in our previous study. ${ }^{11}$ The values reported by FiserovaBergerova and Diaz ${ }^{16}$ were lower than the ones reported by the other investigators. ${ }^{11}{ }^{17}$ Fiserova-Bergerova and Diaz ${ }^{16}$ stated that the use of aqueous standard instead of gas standard may be one of the possible explanations for this discrepancy.

Tissue homogenates in water are generally used to measure tissue/air partition coefficients. Aqueous standard is more natural than gas standard when tissue homogenates are used. In such a measurement, however, an accurate water/air partition coefficient is needed to make the adjustment for solubility in added water.

We report a new head space technique to We water/air partition coefficients for hydrophilic volatile compounds. This method again needs no direct measuremen of the concentration in either the liquid phase or the gas phase; only the gas chromatographic peak areas from both phases. Once the water/air partition coefficient has been determined, the vial equilibration method ${ }^{1}$ can be used to measure the partition coefficients between blood and air, oil and air, and tissue and air. By means of these techniques, we determined partition coefficients of eight acetate esters and eight alcohols in distilled water, olive oil, human blood, and various rat tissues. 
Materials and methods

CHEMICALS AND TEST MATERIALS

Acetate esters (methyl, ethyl, n-propyl, isopropyl, $n$-butyl, iso-butyl, n-pentyl, and isopentyl acetates) and alcohols (methyl, ethyl, n-propyl, iso-propyl, n-butyl, iso-butyl, npentyl, and iso-pentyl alcohols) were purchased from Wako Pure Chemicals (Tokyo) and were of high analytical purity ( $>99 \%)$. The water used had been distilled, and the olive oil was a reagent grade purchased from Tokyo Kasei Co (Tokyo). The human blood was collected from five healthy men (average age 30 , mean packed cell volume $51 \cdot 8 \%$ ) after obtaining informed consent from each volunteer.

Rats were anaesthetised with a sodium pentobarbitone solution. Blood was collected from the abdominal aorta with a heparinised syringe. The liver, kidneys, muscles, brain, and fat were excised and weighed. The tissues, except fat, were homogenised with a known volume of distilled water and an aliquot of the homogenate was used as test material. The net volume of each tissue was calculated assuming that the specific gravity of tissue is unity. The fat tissue was homogenised without adding water, and a portion (approximately $0.5 \mathrm{~g}$ ) was used for partition measurement. The volume of the fat sample was calculated from its average specific gravity of 0.908 .

\section{MEASUREMENTS}

Principle of water/air partition measurement

An aliquot of aqueous solution of each compound is put in an airtight vessel that is kept in a thermoregulated water bath $\left(37^{\circ} \mathrm{C}\right)$ to establish equilibrium between the gas and liquid phases. The concentrations in the liquid and gas phases at equilibrium are designated for convenience as $X_{L}$ and $X_{G}$ moles $/ \mathrm{ml}$ respectively. A volume of liquid $\left(V_{L} \mu l\right)$ of the liquid phase is injected into a gas chromatograph. Gas chromatographic response (peak area) is proportional to the quantity $\left(X_{L} V_{L} \times 10^{-3} \mathrm{~mol}\right)$ introduced into the chromatograph. If the resultant peak area is $A_{L}$ $\mathrm{cm}^{2}$, then

$$
A_{L}=k X_{L} V_{L} \times 10^{-3}
$$

where $k$ is a constant depending on each compound. Equation 1 can be rewritten as:

$$
X_{L}=\left[A_{L} /\left(k V_{L}\right)\right] \times 10^{3}
$$

If $V_{G} \mathrm{ml}$ of the gas phase, which contains $X_{G} V_{G} \mathrm{~mol}$ of the compound, gives $A_{G} \mathrm{~cm}^{2}$ peak area; then the following equation holds:

$$
A_{G}=k X_{G} V_{G}
$$

Hence,

$$
X_{G}=A_{G} /\left(k V_{G}\right)
$$

By definition, $\lambda$ (water/air partition coefficient) $=X_{L} / X_{G}$. From (2) and (4),

$$
\lambda=\frac{A_{L} V_{G}}{A_{G} V_{L}} \times 10^{3}
$$

Thus we can measure the water/air partition coefficient of a hydrophilic volatile compound from only the gas chromatographic peak area ratio between the liquid and gas phases. The advantage of this technique is that the measurement can be made without knowing the exact volume of the equilibration vessel, liquid phase, or gas phase. Also, the partition value is independent of the water concentration of a test compound.

\section{Measurement procedures}

An aqueous solution ( $4 \mathrm{ml}$ ) of each compound $(50 \mu \mathrm{l} / 100 \mathrm{ml})$ was placed in a head space vial (Perkin-Elmer; $22 \mathrm{ml}$ in volume). This was immediately capped with a Teflon lined stopper. The vial was kept at $37^{\circ} \mathrm{C}$ in a water bath with a shaker. After 10 minutes of temperature equilibration, the air pressure in the vessel was made equal to the atmospheric pressure by briefly inserting an air pipe (hypodermic needle) through the stopper. The needle was then removed, and the vessel was kept at $37^{\circ} \mathrm{C}$ for not less than a further 30 minutes to establish the equilibration of the compound between the liquid phase and the overlying air. One millilitre $\left(V_{G}=1\right.$ in equation 5) of the gas phase was withdrawn in a gas tight Hamilton syringe (1002-01) and injected into a gas chromatograph with a hydrogen flame ionisation detector (Hitachi 263). After the peak appeared, $5 \mu \mathrm{l}\left(V_{L}=5\right.$ in equation 5 ) of the liquid phase were injected into the gas chromatograph rapidly with a Hamilton microsyringe (701-02). The peak areas from the gas and liquid phases obtained with an integrator (Hitachi D-2500) were used to calculate the water/air partition coefficient according to equation 5 . The measurement was performed in quintuplicate for each compound.

The operating conditions of the gas chromatograph were: $2 \mathrm{~m} \times 3 \mathrm{~mm}$ glass column packed with PEG-400 on Uniport $B$ (Gasukuro Kogyo, Tokyo) at $80^{\circ} \mathrm{C}$; injection port temperature, $100^{\circ} \mathrm{C}$; carrier gas, $\mathrm{N}_{2}$ at $70 \mathrm{ml} / \mathrm{min} ; \mathrm{H}_{2}$ at $20 \mathrm{ml} / \mathrm{min}$.

As a preliminary trial to examine the usefulness of this technique, the partition coefficient of methyl alcohol, a prototype compound, was measured with three concentrations of water solution $(25,50$, and 100 $\mu \mathrm{l} / 100 \mathrm{ml}$ ) and three volumes of liquid phase $(2,4$, and $8 \mathrm{ml})$. As no significant differences were found among the partition coefficients thus obtained (data not shown), $4 \mathrm{ml}$ of aqueous solution at a concentration of 50 $\mu 1 / 100 \mathrm{ml}$ was used as the liquid phase of each compound in the regular measurement. Gas chromatographic responses (peak areas) from both the gas and liquid phases were linearly related to the concentration of water solution at every volume of the liquid phase used (data not shown).

Blood/air, oil/air, and tissuelair partition coefficients

Blood/air, oil/air, and tissue/air partition coefficients were determined by a previously reported vial equilibration method. ${ }^{11}$ Briefly, 
a $0.1 \mathrm{ml}$ aliquot of an aqueous solution of each compound $(50 \mu \mathrm{l} / 100 \mathrm{ml})$ was put in a sample (containing test material) and a reference vessel (containing no test material). The vessels (Perkin-Elmer, $22 \mathrm{ml}$ head space vials) were then allowed to stand in a thermoregulated water bath with a shaker at $37^{\circ} \mathrm{C}$ for not less than 30 minutes. After the equilibrium was reached, $1 \mathrm{ml}$ of the air in each vessel was injected into a gas chromatograph equipped with a hydrogen flame ionisation detector (Hitachi 263). The operating conditions of this were the same as already described. The peak areas found from the sample and reference vessels were used to calculate the material/air partition coefficients according to the equation reported elsewhere. ${ }^{11}$

The oil/water partition coefficient was calculated as the ratio between oil/air and water/air, and the tissue/blood as the ratio between tissue/air and blood/air.

\section{Results and discussion}

PARTITION COEFFICIENTS OF ACETATE ESTERS Acetate esters could be ranked by their water/air partition coefficients as follows (table 1): methyl $>$ ethyl $>n$-propyl $>$ isopropyl $>n$-butyl $>$ iso-butyl $>n$-pentyl $>$ isopentyl. Thus the water/air partition coefficients decreased as the number of alcoholic carbon atoms increased. The values for $n$-isomers were higher than values for the corresponding iso-isomers.

By contrast with water/air partition coefficients, the oil/air partition coefficients increased with the number of alcoholic carbon atoms (table 1). When the oil/air partition coefficients were used to rank the eight acetate esters, the results were: $n$-pentyl $>$ iso-pentyl $>n$-butyl $>$ iso-butyl $>n$-propyl $>$ iso-propyl $>$ ethyl $>$ methyl. $n$-Isomers were more soluble in oil than the corresponding iso-isomers. Comparing oil/water partition coefficients among eight acetate esters, methyl acetate (oil/water $<1$ ) could be categorised as hydrophilic; $n$-pentyl and iso-pentyl acetates (oil/water $>100$ ) as lipophilic; and ethyl, $n$-propyl, iso-propyl, $n$-butyl and isobutyl acetates $(1<$ oil/water $<100)$ as intermediate compounds.

Body tissues, including blood, contain several esterases, such as carboxylesterases, ${ }^{18} 19$ which may hydrolyse acetate esters and thereby affect the measurement of their tis- sue/air partition coefficients. We found that when ethyl acetate was incubated with intact tissue homogenates, the gas chromatographic peak area from the air in the incubation vessel decreased during the incubation period (fig 1). We therefore concluded that inactivation of esterases was needed to measure tissue/air partition coefficients of acetate esters.

To inhibit the hydrolytic reaction, phenylmethylsulphonyl fluoride (PMSF, from Wako Pure Chemicals, Tokyo), an inhibitor of serine protease, ${ }^{20}$ was used. In pilot studies, PMSF (20 mg/g tissue) was found to block the hydrolysis completely (fig 1). The mean (SD) esterase activities for ethyl acetate were in the liver $18 \cdot 1(1.4)$, kidney $17 \cdot 9(1 \cdot 2)$ and blood $2 \cdot 11(0 \cdot 21) \mu \mathrm{mol} / \mathrm{g} / \mathrm{min}$ of rats as determined from the rate of disappearance of substrate measured in quintuplicate by the method described by Sato and Nakajima. ${ }^{2}$ The activities in the liver and kidney were eight to nine times higher than activity in the blood. Esterase activity was found in every tissue tested, with the lowest activity in the brain. The activity in fresh human blood $(2 \cdot 17(0 \cdot 23) \mu \mathrm{mol} / \mathrm{ml} / \mathrm{min}, \mathrm{n}=5)$ was almost the same as that in rat blood.

Partition coefficients in tissues were measured after 30 minutes preincubation of tissue samples with $\mathrm{PMSF}$ at $37^{\circ} \mathrm{C}$. Human blood/air partition coefficients remained in a narrow range from $33 \cdot 1$ (iso-propyl acetate) to $92 \cdot 4$ ( $n$-pentyl acetate), a $2 \cdot 8$ fold difference (table 1). The solubility in rat blood was

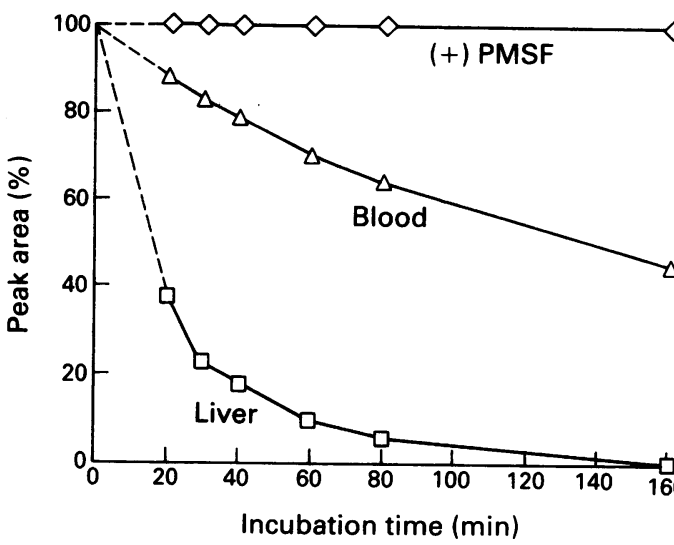

Figure 1 Hydrolysis of ethyl acetate in human blood and rat liver. Peak areas from the air in the incubation vessels where no esterase inhibitor (PMSF) was included were plotted against incubation period. The peak areas from the air in the vessels containing PMSF were counted as $100 \%$

Table 1 Partition coefficients of $C_{1}-C_{5}$ acetate esters in water, olive oil, human blood, and rat blood

\begin{tabular}{|c|c|c|c|c|c|}
\hline Acetate & Waterlair* & Olive oillair* & Oil/watert & Human blood/air* & Rat blood/air* \\
\hline $\begin{array}{l}\text { Methyl } \\
\text { Ethyl } \\
n \text {-Propyl } \\
\text { iso-Propyl } \\
n \text {-Butyl } \\
\text { iso-Butyl } \\
n \text {-Pentyl } \\
\text { iso-Pentyl }\end{array}$ & $\begin{array}{l}108(5) \\
71.5(2.1) \\
53.0(3.0) \\
34.1(2.5) \\
32.7(2.7) \\
25.9(2.1) \\
24.0(1.8) \\
22.6(1.8)\end{array}$ & $\begin{array}{c}85 \cdot 7(11 \cdot 2) \\
176(15) \\
503(37) \\
301(30) \\
1620(90) \\
1280(87) \\
3940(480) \\
2950(280)\end{array}$ & $\begin{array}{c}0.79 \\
2.46 \\
9 \cdot 49 \\
8 \cdot 83 \\
49 \cdot 5 \\
49 \cdot 4 \\
164 \\
131\end{array}$ & $\begin{array}{l}90.1(3.7) \\
76.8(3.4) \\
73.5(1.7) \\
33.1(1.8) \\
83.4(2.9) \\
45.1(2.5) \\
92.4(8.4) \\
59.1(3.0)\end{array}$ & $\begin{array}{l}100(4) \\
81 \cdot 7(4 \cdot 8) \\
76 \cdot 2(4 \cdot 6) \\
35 \cdot 1(3 \cdot 0) \\
89 \cdot 4(5 \cdot 5) \\
52 \cdot 0(4 \cdot 6) \\
96 \cdot 7(8 \cdot 1) \\
64 \cdot 7(4 \cdot 4)\end{array}$ \\
\hline
\end{tabular}

$\star$ Values are means (SD) of five measurements.

tCalculated as (oil/air)/(water/air) 
slightly higher than in human blood, ranging from $35 \cdot 1$ (iso-propyl acetate) to 100 (methyl acetate), a 2.8 fold difference. For human blood, partition coefficients of acetate esters were in the order: $n$-pentyl $>$ methyl $>n$ butyl $>$ ethyl $>n$-propyl $>$ iso-pentyl $>$ isobutyl $>$ iso-propyl. There was no simple relation between the coefficient value and the structure of acetate esters. It is of special interest, however, that $n$-alkyl esters (methyl, ethyl, $n$-propyl, $n$-butyl, and $n$-pentyl acetates) were more soluble in blood than any of the iso-alkyl esters (iso-propyl, iso-butyl, and iso-pentyl acetates).

For every tissue tested, the tissue/air partition coefficient increased as the number of alcoholic carbon atoms increased (table 2). The eight acetate esters could be ranked by tissue/air partition coefficients as follows: $n$ pentyl $>$ iso-pentyl $>n$-butyl $>$ iso-butyl $>n$ propyl $>$ iso-propyl $>$ ethyl $>$ methyl. $n$-Isomers had higher coefficients than the corresponding iso-isomers. For muscle, brain, kidney, and liver, the differences between the highest ( $n$-pentyl acetate) and lowest (methyl acetate) partition coefficients were within a narrow range from 3.4 fold (brain) to 4.9 fold (liver), whereas the difference for fat tissue was 38 fold.

Tissue/blood partition coefficients of methyl acetate were less than unity for all the tissues tested (table 2). The partition coefficients of ethyl acetate ranged from 0.86 (muscle/blood) to 1.87 (fat/blood). All the other acetate esters had partition coefficients larger than unity. Fat/blood partition coefficient of butyl acetate was almost 20 and pentyl acetate almost 40 , a finding which suggests that these two acetate esters behave like lipophilic compounds when inhaled into the body.
PARTITION COEFFICIENTS OF ALCOHOLS

Water/air partition coefficients of eight alcohols decreased in the following order as the number of carbon atoms increased (table 3 ): methyl $>$ ethyl $>n$-propyl $>$ iso-propyl $>n$ butyl $>$ iso-butyl $>n$-pentyl $>$ iso-pentyl. As in the case of acetate esters, $n$-isomers were more soluble in water than the corresponding iso-isomers. By contrast with water/air partition coefficients, the oil/air partition coefficient increased with the number of carbon atoms. Again, $n$-isomers had higher coefficients than the corresponding iso-isomers.

The highest oil/water partition coefficient was 1.28 for $n$-pentyl alcohol, followed by 1.19 for iso-pentyl alcohol (table 3). The coefficients for methyl, ethyl, n-propyl, isopropyl, $n$-butyl, and iso-butyl alcohols were all less than unity. This indicates that alcohols are much more hydrophilic than acetate esters when comparing oil/water partition coefficients for the same number of alcoholic carbon atoms.

All alcohols tested were more soluble in rat blood than in human blood (table 3). Both human and rat blood/air partition coefficients were almost parallel to the water/air partition coefficients (fig 2). The blood/air partition coefficients decreased in the following order as the number of carbon atoms increased: methyl $>$ ethyl $>n$-propyl $>$ iso-propyl $>n$-butyl $>$ iso-butyl $>n$-pentyl $>$ iso-pentyl. The coefficients of $n$-isomers were higher than the coefficients of the corresponding isoisomers.

The eight alcohols could be ranked by muscle/air, brain/air, kidney/air, and liver/air partition coefficients almost in the same order as ranked by the blood/air partition coefficients, whereas the order of fat/air partition coefficients was almost inversely related to

Table 2 Partition coefficients of $C_{1}-C_{5}$ acetate esters in rat tissues

\begin{tabular}{|c|c|c|c|c|c|c|c|c|c|c|}
\hline Acetate & Musclelair* & Brain/air* & Kidney/air* & Liver/air* & Fatlair* & $\begin{array}{l}\text { Musclel } \\
\text { bloodt }\end{array}$ & $\begin{array}{l}\text { Brain/ } \\
\text { bloodt }\end{array}$ & $\begin{array}{l}\text { Kidney/ } \\
\text { blood }\end{array}$ & $\begin{array}{l}\text { Liverl } \\
\text { blood } \dagger\end{array}$ & Fat/bloodt \\
\hline $\begin{array}{l}\text { Methyl } \\
\text { Ethyl } \\
n \text {-Propyl } \\
\text { iso-Propyl } \\
n \text {-Butyl } \\
\text { iso-Butyl } \\
n \text {-Pentyl } \\
\text { iso-Pentyl }\end{array}$ & $\begin{array}{c}65 \cdot 1(14 \cdot 2) \\
69 \cdot 9(7 \cdot 6) \\
84 \cdot 7(9 \cdot 7) \\
70 \cdot 9(9 \cdot 4) \\
157(15) \\
110(9) \\
230(31) \\
209(17)\end{array}$ & $\begin{array}{l}70 \cdot 1(6 \cdot 7) \\
80 \cdot 0(8 \cdot 4) \\
99 \cdot 9(16 \cdot 6) \\
88 \cdot 9(12 \cdot 4) \\
165(21) \\
138(10) \\
240(12) \\
221(13)\end{array}$ & $\begin{array}{l}82 \cdot 6(6 \cdot 2) \\
87 \cdot 6(12 \cdot 1) \\
197(22) \\
142(16) \\
243(26) \\
212(22) \\
324(30) \\
299(10)\end{array}$ & $\begin{array}{l}89 \cdot 0(9 \cdot 8) \\
107(17) \\
230(22) \\
148(8) \\
281(19) \\
263(25) \\
435(16) \\
355(25)\end{array}$ & $\begin{array}{l}99 \cdot 0(7 \cdot 3) \\
153(8) \\
514(30) \\
303(27) \\
1520(59) \\
1110(78) \\
3730(130) \\
2750(180)\end{array}$ & $\begin{array}{l}1 \cdot 11 \\
2.02 \\
1 \cdot 76 \\
2 \cdot 12 \\
2 \cdot 38 \\
3 \cdot 23\end{array}$ & $\begin{array}{l}1.31 \\
2.53 \\
1.85 \\
2.65 \\
2.48 \\
3.42\end{array}$ & $\begin{array}{l}0 \cdot 83 \\
1.07 \\
2 \cdot 59 \\
4 \cdot 05 \\
2 \cdot 72 \\
4 \cdot 08 \\
3 \cdot 35 \\
4 \cdot 62\end{array}$ & $\begin{array}{l}0 \cdot 89 \\
1 \cdot 31 \\
3 \cdot 02 \\
4 \cdot 22 \\
3 \cdot 14 \\
5 \cdot 06 \\
4 \cdot 50 \\
5 \cdot 49\end{array}$ & $\begin{array}{c}0.99 \\
1.87 \\
6 \cdot 75 \\
8.63 \\
17 \cdot 0 \\
21 \cdot 3 \\
38.6 \\
42 \cdot 5\end{array}$ \\
\hline
\end{tabular}

*Values are means $(\mathrm{SD})$ of five measurements.

†Calculated as (tissue/air)/(blood/air).

Table 3 Partition coefficients of $C_{1}-C_{5}$ alcohols in water, olive oil, human blood, and rat blood

\begin{tabular}{|c|c|c|c|c|c|}
\hline Alcohol & Water/air * & Olive oillair* & Oil/Watert & Human blood/air* & Rat bloodlair * \\
\hline $\begin{array}{l}\text { Methyl } \\
\text { Ethyl } \\
n \text {-Propyl } \\
\text { iso-Propyl } \\
n \text {-Butyl } \\
\text { iso-Butyl } \\
n \text {-Pentyl } \\
\text { iso-Pentyl }\end{array}$ & $\begin{array}{l}3330(320) \\
2140(200) \\
1850(170) \\
1500(74) \\
1310(220) \\
1130(37) \\
1080(27) \\
850(50)\end{array}$ & $\begin{array}{c}82 \cdot 5(6 \cdot 4) \\
109(10) \\
297(38) \\
154(13) \\
759(87) \\
471(55) \\
1380(130) \\
1010(100)\end{array}$ & $\begin{array}{l}0.025 \\
0.051 \\
0 \cdot 161 \\
0 \cdot 103 \\
0 \cdot 579 \\
0 \cdot 417 \\
1 \cdot 28 \\
1 \cdot 19\end{array}$ & $\begin{array}{c}2590(270) \\
1440(94) \\
1120(76) \\
848(43) \\
677(79) \\
578(75) \\
534(23) \\
381(16)\end{array}$ & $\begin{array}{l}3440(76) \\
2140(180) \\
1340(54) \\
1290(46) \\
1160(39) \\
880(37) \\
829(56) \\
533(42)\end{array}$ \\
\hline
\end{tabular}

*Values are means (SD) of five measurements.

†Calculated as (oil/air)/(water/air). 
Table 4 Partition coefficients of $C_{1}-C_{5}$ alcohols in rat tissues

\begin{tabular}{|c|c|c|c|c|c|c|c|c|c|c|}
\hline Alcohol & Muscle/air* & Brain/air* & Kidney/air ${ }^{*}$ & Liver/air* & Fat/air* & $\begin{array}{l}\text { Muscle } \\
\text { bloodt }\end{array}$ & $\begin{array}{l}\text { Brain/ } \\
\text { bloodt }\end{array}$ & $\begin{array}{l}\text { Kidneyl } \\
\text { bloodt }\end{array}$ & $\begin{array}{l}\text { Liverl } \\
\text { bloodt }\end{array}$ & Fat/blood $†$ \\
\hline $\begin{array}{l}\text { Methyl } \\
\text { Ethyl } \\
n \text {-Propyl } \\
\text { iso-Propyl } \\
n \text {-Butyl } \\
\text { iso-Butyl } \\
n \text {-Pentyl } \\
\text { iso-Pentyl }\end{array}$ & $\begin{array}{c}3980(180) \\
1710(230) \\
1140(100) \\
1100(120) \\
900(130) \\
850(66) \\
814(85) \\
788(94)\end{array}$ & $\begin{array}{c}3470(300) \\
1870(81) \\
1220(71) \\
1130(40) \\
1140(38) \\
868(22) \\
1080(89) \\
614(32)\end{array}$ & $\begin{array}{c}3190(170) \\
2030(120) \\
1240(38) \\
1060(23) \\
1160(95) \\
875(42) \\
1100(120) \\
717(23)\end{array}$ & $\begin{array}{c}3090(180) \\
1730(160) \\
1290(51) \\
980(120) \\
1250(44) \\
880(100) \\
1750(250) \\
940(30)\end{array}$ & $\begin{array}{c}193(36) \\
226(13) \\
402(34) \\
274(26) \\
900(49) \\
720(52) \\
2560(190) \\
1500(130)\end{array}$ & $\begin{array}{l}1 \cdot 16 \\
0.80 \\
0.85 \\
0.85 \\
0.78 \\
0.97 \\
0.98 \\
1.48\end{array}$ & $\begin{array}{l}1.01 \\
0.87 \\
0.91 \\
0.88 \\
0.98 \\
0.99 \\
1.30 \\
1.15\end{array}$ & $\begin{array}{l}0.93 \\
0.95 \\
0.93 \\
0.82 \\
1.00 \\
0.99 \\
1.33 \\
1.35\end{array}$ & $\begin{array}{l}0.90 \\
0.81 \\
0.96 \\
0.76 \\
1.08 \\
1.00 \\
2.11 \\
1.76\end{array}$ & $\begin{array}{l}0 \cdot 06 \\
0 \cdot 11 \\
0 \cdot 30 \\
0 \cdot 21 \\
0 \cdot 78 \\
0 \cdot 82 \\
3 \cdot 09 \\
2 \cdot 81\end{array}$ \\
\hline
\end{tabular}

* Values are means (SD) of five measurements.

†Calculated as (tissue/air)/(blood/air).

Figure 2 Relation between human bloodlair partition coefficient and waterlair partition coefficient (alcohol data). $1=$ methyl alcohol; 2 = ethyl alcohol; 3 = n-propyl alcohol; 4 = iso-propyl alcohol; 5 = n-butyl alcohol; $6=$ iso-butyl alcohol $7=$ n-pentyl alcohol; $8=$ iso-pentyl alcohol.

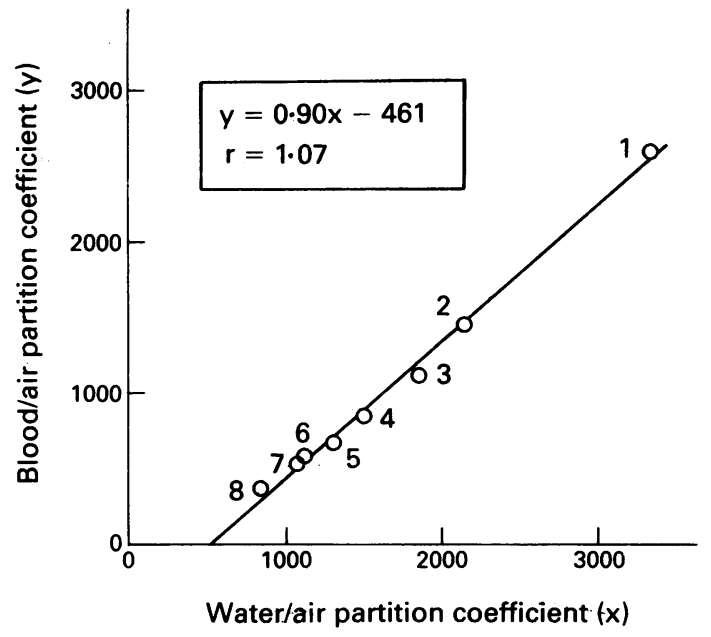

the order of blood/air partition coefficients (table 4). $n$-Isomers had higher partition values than the corresponding iso-isomers.

The tissue/blood partition coefficients of all alcohols tested were in the vicinity of unity, except for fat/blood partition coefficients which ranged from 0.06 (methyl alcohol) to 3.09 (iso-pentyl alcohol) (table 4). The data in table 4 suggest that methyl, ethyl, and propyl alcohols may preferentially distribute in the lean body tissues, whereas butyl and pentyl alcohols may uniformly distribute throughout the body.

The partition coefficients of some alcohols (methyl, ethyl, $n$-propyl, iso-propyl, and isobutyl) between human blood and air reported by Fiserova-Bergerova and Diaz ${ }^{16}$ were much lower than the corresponding values in our study. For example, the value of the blood/air partition coefficient for methyl alcohol (2590) in this study was 1.6 times higher than the value (1626) given by Fiserova-Bergerova and Diaz. At present, no explanation is available for this discrepancy, except that because they used a gas standard, the air in the reference vessel in their study must have been almost dry (the vapour pressure was low) whereas the sample vessel was saturated with water vapour. This difference in the water vapour pressure may affect partition coefficients of such highly hydrophilic compounds as methyl alcohol. In fact, when we measured blood/air partition coefficient of methyl alcohol in essentially the same way as described by Fiserova-Bergerova and Diaz with a gas standard, ${ }^{16}$ the resultant coefficient value was
1780 (180) $(n=5)$, which is significantly lower than the value in the present study but almost comparable with the one given by Fiserova-Bergerova and Diaz. It should be remembered that alveolar air is saturated with water vapour.

1 Fiserova-Bergerova V, Vlach J, Singhal K. Simulation and prediction of uptake, distribution, and exhalation of organic solvents. $\mathrm{Br}$ F Ind Med 1974;31:45-52.

2 Guberan E, Fernandez JG. Control of industrial exposure to tetrachloroethylene by measuring alveolar concentrato tetrachloroethylene by measuring alveolar concentrations: theoretical approach usin
$B r \mathcal{F}$ Ind Med 1974;31:159-67.

3 Fernandez JG, Droz PO, Humbert BE, Caperos JR Trichloroethylene exposure. Simulation of uptake, excretion, and metabolism using a mathematical mode. Br F Ind Med 1977;34:43-55.

4 Ramsey JC, Andersen ME. A physiologically based description of the inhalation pharmacokinetics of styrene in rats and humans. Toxicol Appl Pharmacol 1984;73:159-75.

5 Koizumi A. Potential of physiologically based pharmacokinetics to amalgamate kinetic data of trichloroethylene and tetrachloroethylene obtained in rats and man. $\mathrm{Br} F$ Ind Med 1989;46:239-49.

6 Kaneko T, Endoh K, Sato A. Biological monitoring of exposure to organic solvent vapors I. A physiological simulation model of $m$-xylene pharmacokinetics in man. Simulation model of m-xylene pharmacokinet

7 Kaneko T, Endoh K, Sato A. Biological monitoring of exposure to organic solvent vapors II. Simulation studies using a physiological pharmacokinetic model for $m$ xylene. Yamanashi Medical fournal 1991;6:137-49.

8 Johanson G, Näslund PH. Spreadsheet programming-a new approach in physiologically based modeling of solvent toxicokinetics. Toxicol Lett 1988;41:115-27.

9 Johanson G. Modelling of respiratory exchange of polar solvents. Ann Occup Hyg 1991;35:323-39.

10 Horton VL, Higuchi MA, Rickert DE. Physiologically based pharmacokinetic model for methanol in rats, monkeys, and humans. Toxicol Appl Pharmacol 1992;117:26-36.

11 Sato A, Nakajima T. Partition coefficients of some aromatic hydrocarbons and ketones in water, blood, and matic hydrocarbons and ketones
oil. Br f Ind Med 1979;36:231-4.

12 Sato A, Nakajima T. A structure-activity relationship of some chlorinated hydrocarbons. Arch Environ Health 1979;34:69-75.

13 Perbellini L, Brugnone F, Carretta D, Maranelli .G. Partition coefficients of some industrial aliphatic hydrocarbons $\left(\mathrm{C}_{5}-\mathrm{C}_{7}\right)$ in blood and humans. Br $\mathcal{F}$ Ind Med 1985;42:162-7.

14 Gargas ML, Burgess RJ, Voisard DE, Cason GH, Andersen ME. Partition coefficients of low-molecularweight volatile chemicals in various liquids and tissues. Toxicol Appl Pharmacol 1989;98:87-99.

15 Falk A, Gullstrand E, Löf A, Wigaeus-Hjelm E. Liquid/air partition coefficients of four terpenes. $\mathrm{Br} \mathcal{F}$ Ind Med 1990;47:62-4.

16 Fiserova-Bergerova V, Diaz ML. Determination and prediction of tissue-gas partition coefficient. Int Arch Occup Environ Health 1986;58:75-87.

17 Pezzagno G, Ghittori S, Imbriani M. Respiratory measurements of occupational exposure to industrial solsurements of occupational exposure
vents. G Ital Med Lav 1985;7:1 7-34.

18 Morris JB. First-pass metabolism of inspired ethyl acetate in the upper respiratory tracts of the F344 rat and Syrian hamster. Toxicol Appl Pharmacol

19 Gallaher EJ, Loomis TA. Metabolism of ethyl acetate in the rat: hydrolysis to ethyl alcohol in vitro and in vivo. Toxicol Appl Pharmacol 1975;35:323-39.

20 James GT. Inactivation of the protease inhibitor phenylmethylsulfonyl fluoride in buffers. Anal Biochem 1978;86:574-9.

21 Sato A, Nakajima T. A vial-equilibration method to evaluate the drug-metabolizing enzyme activity for volatile hydrocarbons. Toxicol Appl Pharmacol 1979;47:41-6. 